\title{
METHOD OF ESTIMATING NATURAL RECHARGE TO THE EDWARDS AQUIFER IN THE SAN ANTONIO AREA, TEXAS
}

\section{U.S. GEOLOGICAL SURVEY}

Water-Resources Investigations 78-10

Prepared in cooperation with the Texas Department of Water Resources, the Edwards Underground Water District, and the city of San Antonio 


\begin{tabular}{|c|c|c|}
\hline $\begin{array}{l}\text { BIBLIOGRAPHIC DATA } \\
\text { SHEET }\end{array}$ & 1. Report No. & 3. Recipient's Accession No. \\
\hline \multirow{2}{*}{\multicolumn{2}{|c|}{$\begin{array}{l}\text { 4. Title and Subtitle } \\
\text { METHOD OF ESTIMATING NATURAL RECHARGE TO THE EDWARDS } \\
\text { AQUIFER IN THE SAN ANTONIO AREA, TEXAS }\end{array}$}} & $\begin{array}{l}\text { 5. Report Date } \\
\text { April } 1978\end{array}$ \\
\hline & & 6. \\
\hline \multicolumn{2}{|l|}{$\begin{array}{l}\text { 7. Author(s) } \\
\text { Celso Puente }\end{array}$} & $\begin{array}{l}\text { 8. Performing Organization Rept. } \\
\text { No. USGS/WRI }-78-10\end{array}$ \\
\hline \multirow{2}{*}{\multicolumn{2}{|c|}{$\begin{array}{l}\text { 9. Performing Organization Name and Address } \\
\text { U.S. Geological Survey, Water Resources Division } \\
\text { 300 E. Eighth Street } \\
\text { Austin, TX } 78701\end{array}$}} & 10. Project/Task/Work Unit No. \\
\hline & & 11. Contract/Grant No. \\
\hline \multirow{2}{*}{\multicolumn{2}{|c|}{$\begin{array}{l}\text { 12. Sponsoring Organization Name and Address } \\
\text { U.S. Geological Survey, Water Resources Division } \\
\text { 300 E. Eighth Street } \\
\text { Austin, TX } 78701\end{array}$}} & $\begin{array}{l}\text { 13. Type of Report \& Period } \\
\text { Covered } \\
\text { Final }\end{array}$ \\
\hline & & 14. \\
\hline
\end{tabular}

15. Supplementary Notes

Prepared in cooperation with the Texas Department of Water Resources, the Edwards Underground Water District, and the city of San Antonio

16. Abstracts

The method of estimating annual recharge is based on data collected from a network of stream-gaging stations and on assumptions related to applying the runoff characteristics from gaged areas to ungaged areas. The basic approach is a water-balance equation, in which recharge within a stream basin is the difference between measured streamflow above and below the infiltration area of the aquifer plus the estimated runoff in the zone that includes the infiltration area. Recharge in the Medina River basin also includes seepage losses from Medina Lake and Diversion Reservoir.

The principal errors in the estimates of annual recharge are related to errors in estimating runoff in ungaged areas, which represent about 30 percent of the infiltration area. The estimated long-term average annul recharge in each basin, however, is probably representative of the actual recharge because the averaging procedure tends to cancel out the major errors.

17. Key Words and Document Analysis. 170. Descriptors

*Ground-water recharge, Ground-water basins, Aquifers, Aquifer characteristics, Surface-ground-water relationships, Water sources, Infiltration

17b. Identifiers/Open-Ended Terms

Limestone hydrology; Bexar County, Texas; Balcones Fault Zone

17c. COSATI Field/Group

\begin{tabular}{|c|c|c|}
\hline $\begin{array}{l}\text { 18. Availability Statement } \\
\text { No restriction on distribution. }\end{array}$ & $\begin{array}{l}\text { 19. Security Class (This } \\
\text { Report) } \\
\text { UNCLASSIFIED }\end{array}$ & $\begin{array}{l}\text { 21. No. of Pages } \\
38\end{array}$ \\
\hline & $\begin{array}{l}\text { 20. Security Class (This } \\
\text { Page } \\
\text { UNCLASSIFIED }\end{array}$ & 22. Price \\
\hline
\end{tabular}




\section{METHOD OF ESTIMATING NATURAL \\ RECHARGE TO THE EDWARDS \\ AQUIFER IN THE SAN ANTONIO \\ AREA, TEXAS}

By Celso Puente

U.S. GEOLOGICAL SURVEY

Water-Resources Investigations 78-10

Prepared in cooperation with the Texas Department of Water Resources, the Edwards Underground Water District, and the city of San Antonio

APRIL 1978 
Reproduced by the Texas Department of Water Resources as a part of the continuing program of cooperation in water-resources investigations between the Department and the U.S. Geological Survey.

Copies of this report may be obtained from the

U.S. Geological Survey Federal Building 300 East 8 th Street Austin, TX 78701 


\title{
UNITED STATES DEPARTMENT OF THE INTERIOR
}

\author{
Cecil D. Andrus, Secretary
}

\author{
GEOLOGICAL SURVEY \\ W. A. Radlinski, Acting Director
}

FOR ADDITIONAL INFORMATION WRITE TO:

U.S. GEOLOGICAL SURVEY

FEDERAL BUILDING

300 EAST 8TH STREET

AUSTIN, TX 78701 
Abstract-

Introduction-

Geology and hydrology-

Method of determining annual recharge-(-

Basic approach-_... 5

Estimated runoff between upper and lower gages-_........ 6

Adjustments for distribution of precipitation- 16

Recharge in individual basins- 17

Nueces-West Nueces River basin-_. 17

Frio-Dry Frio River basin and adjacent areas-_._. 18

Sabinal River basin and adjacent areas-_. 20

Area between the Sabinal River basin and the Medina

River basin-.. 21

Medina River basin-. 23

Area between the Medina River basin and the Cibolo Creek

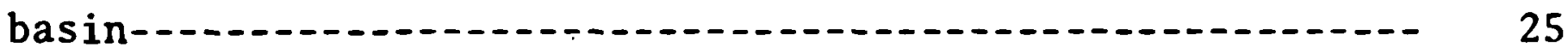

Cibolo Creek and Dry Comal Creek basins-_. 26

Cibolo Creek basin-_...... 26

Dry Comal Creek basin-_. 27

Guadalupe River basin-_... 28

Blanco River basin and adjacent area-_. 28

Conclusions-1.

Selected references- 


\section{ILLUSTRATIONS}

Page

Figure 1. Map showing drainage basins and data-collection sites in the San Antonio area-...-

2. Map showing geologic and hydrologic features in the San Antonio area-...

3. Graphical separation of a hypothetical hydrograph for estimating the components of direct precipitation-1...

4.-11. Graphs showing:

4. Relationship between the base flow of the Nueces River at Laguna and ground-water storage contributing to base flow in the Nueces River basin-.....-

5. Relationship between the base flow of the Frio River at Concan and ground-water storage contributing to base flow in the Frio River basin-........

6. Relationship between the base flow of the Dry Frio River near Reagan Wells and ground-water storage contributing to base flow in the Dry Frio River basin-........

7. Relationship between the base flow of the Sabinal River near Sabinal and ground-water storage contributing to base flow in the Sabinal River basin- lationship between the base flow of Seco Creek

8. Relationship between the base flow of Seco Creek
at Miller Ranch near Utopia and ground-water storage contributing to base flow in the Seco

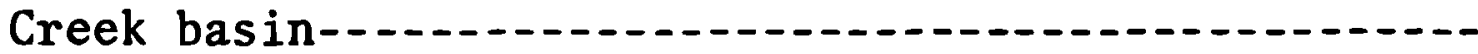

9. Relationship between the base flow of Hondo Creek near Tarpley and ground-water storage contributing to base flow in the Hondo Creek basin-

10. Relationship between the base flow of the Blanco River at Wimberley and ground-water storage contributing to base flow in the Blanco River

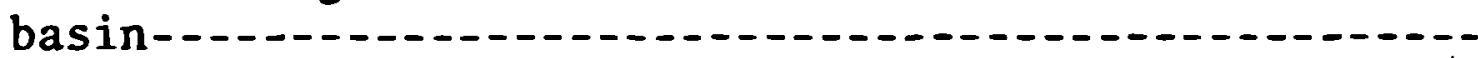

11. Relationship between the monthly average contents of Medina Lake and recharge to the Edwards aquifer from Medina Lake and Diversion Reservoir-..........

TABLE

Table 1. Estimated annual recharge to the Edwards aquifer by basins, 1934-75 
METHOD OF ESTIMATING NATURAL RECHARGE TO THE

EDWARDS AQUIFER IN THE SAN ANTONIO AREA, TEXAS

By

Celso Puente

U.S. Geological Survey

\begin{abstract}
Estimates of annual recharge to the Edwards aquifer in the San Antonio area, Texas, have been made by several investigators as part of the longterm studies of the aquifer by the U.S. Geological Survey under agreements with several local cooperators.

The method of estimating annual recharge is based on data collected from a network of stream-gaging stations and on assumptions related to applying the runoff characteristics from gaged areas to ungaged areas. The basic approach is a water-balance equation, in which recharge within a stream basin is the difference between measured streamflow above and below the infiltration area of the aquifer plus the estimated runoff in the zone that includes the infiltration area. Recharge in the Medina River basin also includes seepage losses from Medina Lake and Diversion Reservoir.

Gaging stations are located above and below the infiltration area in five of the nine basins that have been delineated. Gaging stations above and below the infiltration area are located in parts of the other four basins. Parts of two basins have stations only at points below the infiltration area, and parts of the other two basins have no gaging sites at all.
\end{abstract}

The principal errors in the estimates of annual recharge are related to errors in estimating runoff in ungaged areas, which represent about 30 percent of the infiltration area. The estimated long-term average annual recharge in each basin, however, is probably representative of the actual recharge because the averaging procedure tends to cancel out the major errors. 


\section{INTRODUCT ION}

The purpose of this report is to present the method used, with periodic modifications since about 1955, for estimating natural recharge to the Edwards aquifer, the primary source of water in the San Antonio area, Texas. The method is based on data collected from a network of streamgaging stations (fig. 1) and on assumptions related to applying the runoff characteristics from gaged areas to ungaged areas. Several investigators have used the method to estimate monthly and annual recharge for various periods since 1934 (Lowry, 1955; Petitt and George, 1956; Garza, 1962, 1966; Rettman, 1966-70; Puente, 1971-75). The collection of data used in these studies is part of a program of hydrologic investigations by the U.S. Geological Survey in cooperation with the Edwards Underground Water District, the Texas Department of Water Resources (formerly Texas Water Deve1opment Board), and the city of San Antonio.

Estimates of recharge are made for each individual basin within the study area by use of a computer program, in which input data consist of drainage areas, streamflow records, and precipitation records. Most of the area is within the major basins of the Nueces and Guadalupe Rivers and consists of the following smaller basins: (1) Nueces-West Nueces River basin; (2) Frio-Dry Frio River basin; (3) Sabinal River basin; (4) the area between the Sabinal and Medina River basins; (5) Medina River basin; (6) the area between the Medina River and Cibolo Creek basins; (7) the Cibolo Creek and Dry Comal Creek basins; (8) the Guadalupe River basin; and (9) the Blanco River basin and adjacent area (area between the Guadalupe River basin and the Blanco River basin).

\section{GEOLOGY AND HYDROLOGY}

The regional geology and hydrology of the Edwards aquifer in the San Antonio area has been studied by Petitt and George (1956), Garza (1962, 1966), and Maclay and Small (1976). The drainage areas affecting recharge to the Edwards aquifer are within two physiographic provinces, the Edwards Plateau section of the Great Plains province and the West Gulf Coastal Plain section of the Coastal Plains province, which are separated by an intensively faulted area known as the Balcones Fault Zone.

The Edwards aquifer as defined in this report consists of part of the Edwards and associated limestones of Cretaceous age (fig. 2), with hydraulic boundaries consisting of (1) the limits of the infiltration area on the north, (2) a ground-water divide in Kinney County to the west, (3) a groundwater divide in Hays County to the east, and (4) a zone of inferior water, arbitrarily delineated by the "bad-water" line, at the southern limits of the artesian area. The infiltration area, as delineated in this report, consists of the area shown on figure 2. The infiltration area consists of (1) the delineated outcrop of the Edwards aquifer as shown for areas east of Uvalde County; and (2) the delineated outcrop of the aquifer, based on surface- and ground-water divides, that separate the Edwards aquifer and the Edwards Plateau aquifer in Uvalde and Kinney Counties. The Edwards aquifer in the San Antonio area is about $180 \mathrm{miles}$ long and varies in width from about 5 to 30 miles (fig. 2). 


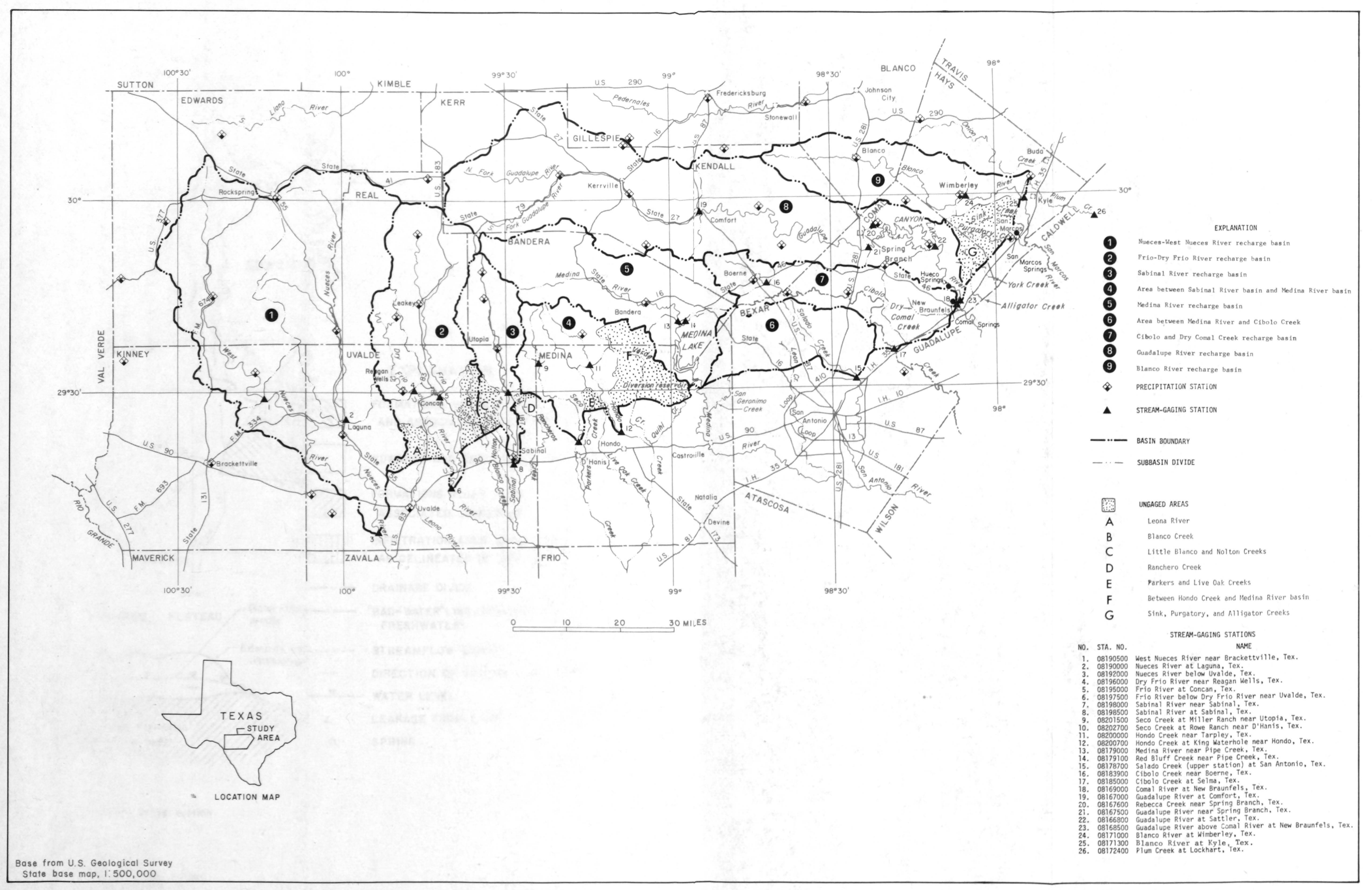

FIGURE 1.-Drainage basins and data-collection sites in the San Antonio area 


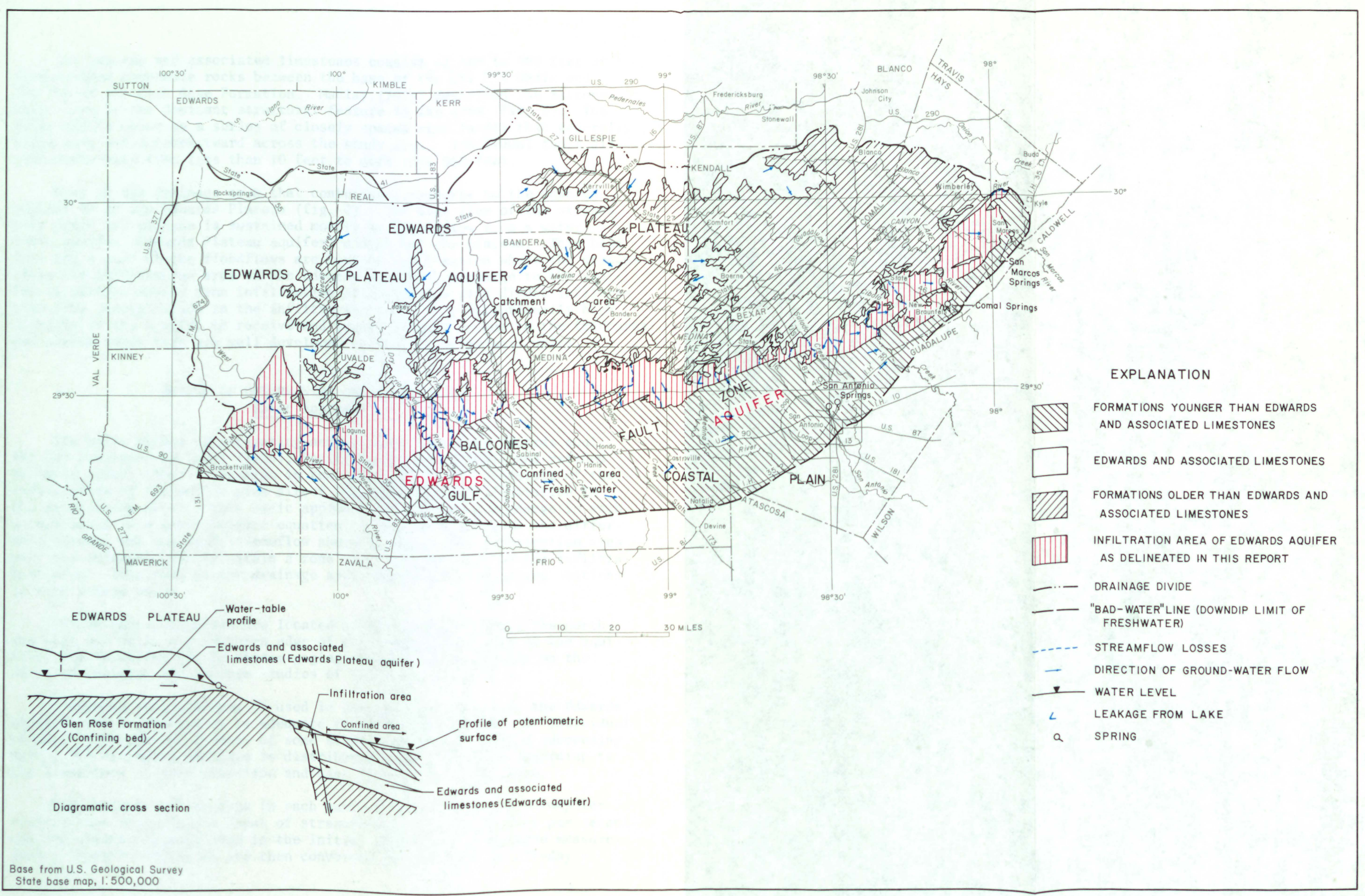

FIGURE 2.-Geologic and hydrologic features in the San Antonio area 
The Edwards and associated limestones consist of 400 to 500 feet of fine-grained carbonate rocks between the base of the Del Rio Shale and the top of the Glen Rose Formation. Maclay (1973) describes the Balcones Fault Zone as the dominant structural feature in the area (fig. 2). The major faults occur as a series of closely spaced step faults that generally trend east and northeastward across the study area. Individual fault displacements vary from less than 10 feet to more than 500 feet.

Most of the drainage area that contributes recharge to the Edwards aquifer is on the Edwards Plateau (fig. 2). The base flow of the streams that drain the plateau is sustained mostly by springflow from a watertable aquifer (Edwards Plateau aquifer) underlying the plateau. This base flow and a part of the floodflows are lost by infiltration where the streams cross the infiltration area of the Edwards aquifer. Recharge to the aquifer is derived mainly from infiltration of streamflow plus direct infiltration from precipitation in the infiltration area. The exceptionally high capacity of the aquifer to receive and transmit water is due to the fractures and porous zones that are well developed in some stratigraphic units.

METHOD OF DETERMINING ANNUAL RECHARGE Basic Approach

The basic method of estimating annual recharge to the Edwards aquifer was developed by Lowry (1955), Petitt and George (1956), and refined by Garza (1962, 1966). Recharge in the infiltration area consists of the infiltration of streamflow plus direct infiltration of precipitation in the interstream areas. This basic approach of estimating recharge in each strean basin is a water-balance equation, in which recharge is the difference between the measured streamflow above and below the infiltration area plus the estimated runoff within a zone that includes part of the infiltration area. This zone is the drainage area between the two gaging stations in each stream basin.

Stream-gaging stations are located a short distance above the northern edge and below the southern edge of the infiltration area of the aquifer. The locations of the stream-gaging stations were selected on the basis of geologic and seepage studies of the streams involved.

A monthly time interval is used in estimating recharge to the Edwards aquifer, and it appears to be adequate to permit the analysis of individual storms. Although the effects of some storms may overlap into a succeeding month, the estimated recharge is distributed proportionately according to the occurrence of both floodflow and base flow during each month.

The estimate of recharge in each basin is made by use of a computer program that requires the input of streamflow data in cubic fect per seconddays (cfs-days), a unit used in the initial handling of discharge measurements. Monthly estimates are then converted to acre-feet ( 1 cfs-day $=$ 
1.9835 acre-feet). The basic equation for computing monthly recharge is as follows:

$$
R=\left(Q_{U}+S I-Q_{L}\right)(1.9835)
$$

where $\underline{R}$ is monthly recharge, in acre-feet;

$\mathrm{Q}_{U}$ is the volume of flow at the upper gage, in cfs-days;

$\underline{\text { SI }}$ is the estimated volume of runoff (including infiltration) resulting from precipitation in the intervening area, in cfs-days; and

$\mathrm{Q}_{\mathrm{L}}$ is the volume of flow at the lower gage, in cfs-days.

Streamflow data are available for most of the basins within the infiltration area; however, some of the streams are ungaged because suitable sites for the installation of gages are not available. Approximately 30 percent of the total infiltration area is ungaged. The estimated amounts of recharge in the ungaged areas are based on the assumption that the runoff characteristics are similar to the runoff characteristics of the adjacent gaged areas. The procedures are explained in the detailed analyses of the individual basins.

\section{Estimated Runoff Between Upper and Lower Gages}

The runoff resulting from direct precipitation in the drainage area between the upper and lower gaging stations can be a significant factor in the water-balance equation. Part of this runoff may percolate downward in the infiltration area, and part may eventually contribute to streamflow between the gages. Obviously, this total runoff cannot be gaged and cannot be separated into seepage or runoff components, but the inability to separate it does not affect the water-balance equation. However, a good estimate of the total runoff is required.

The flow measured at each upper gaging station is composed of both floodflow and base flow. Floodflow, which is water that enters the stream by direct runoff during and immediately after a rainstorm, reaches the gage rapidly and is characterized by a sharp increase in discharge. Floodflows quickly recede and cease until the next rainstorm.

Base flow is the part of the streamflow that is sustained mainly by springs, and to a lesser degree of seepage from bank storage. The springs, which drain the water-table aquifer in the catchment area of the Edwards Plateau (figs. 1 and 2), occur where the water table is intersected by the deep valleys. Most of the springs occur at an altitude above flood stages of the streams; therefore, rises in stream level do not affect the discharge of the springs.

Hydrographs of streamflow data from the upper gaging stations can be separated to indicate the relative amounts of base flow and floodflow from the Edwards Plateau. For each storm, floodflow within the areas between the upper and lower gages is assumed to occur at the same rate per unit 
area as above the upper gage. Stream losses due to evapotranspiration are assumed to be proportionately the same for both the infiltration area and the catchment area on the Edwards Plateau.

The general equation used for estimating the total runoff derived from direct precipitation in the areas between the upper and lower gages is expressed as follows:

$$
S I=\frac{\Delta A}{A_{u}} Q_{t u}
$$

where SI is the volume of water (runoff plus infiltration) contributed by precipitation in the intervening drainage area, in cfs-days;

$\Delta \mathrm{A}$ is the intervening drainage area between the upper and lower gage, in square miles;

$A_{u}$ is the drainage area above the upper gage, in square miles; and

$\mathrm{Q}_{\mathrm{tu}}$ is the volume of water contributed by the storm above the upper gage, in cfs-days.

Figure 3 is a hypothetical hydrograph that illustrates graphical separation of the streamflow components and their relation to rainstorms. The floodflow component (C) is empirically separated from the base flow and should be considered as an approximation. The floodflow component (C) is only a part of Qtu; the other part is the amount of water that infiltrates the surface of the Edwards Plateau and becomes base flow during and after a storm. The increase in base flow from a storm (cross-hatched area on fig. 3) can be computed from the differences between the base-flow recession curves before and after the storm. However, succeeding storms often overlap streamflow recessions, and base-flow components for each storm are difficult to separate.

The magnitude of the base flow of streams draining the Edwards Plateau is directly dependent on the quantity of water stored in the water-table aquifer underlying the plateau. Long-term streamflow records at upper gaging stations have been used to develop base-flow recession curves on the basis of data collected during the winter, when storms and evapotranspiration losses are at a minimum. These recession curves have been used to construct the graphs (figs. 4-10) showing the relation between groundwater storage in the Edwards Plateau aquifer contributing to base flow and the base flow of the streams.

An increase in the base flow as the result of a storm can be applied to the graphs (figs. 4-10) to determine the corresponding increase in storage in the Edwards Plateau aquifer, which is equivalent to the base-flow contribution of the storm during the streamflow recession (component $B$ on fig. 3). Graphs relating base flow to storage in the Edwards Plateau aquifer have been developed for the following gaging stations: Nueces River at Laguna (fig. 4); Frio River at Concan (fig. 5); Dry Frio River near Reagan Wells (fig. 6); Sabinal River near Sabinal (fig. 7); Seco Creek at 


$$
\underline{t}
$$




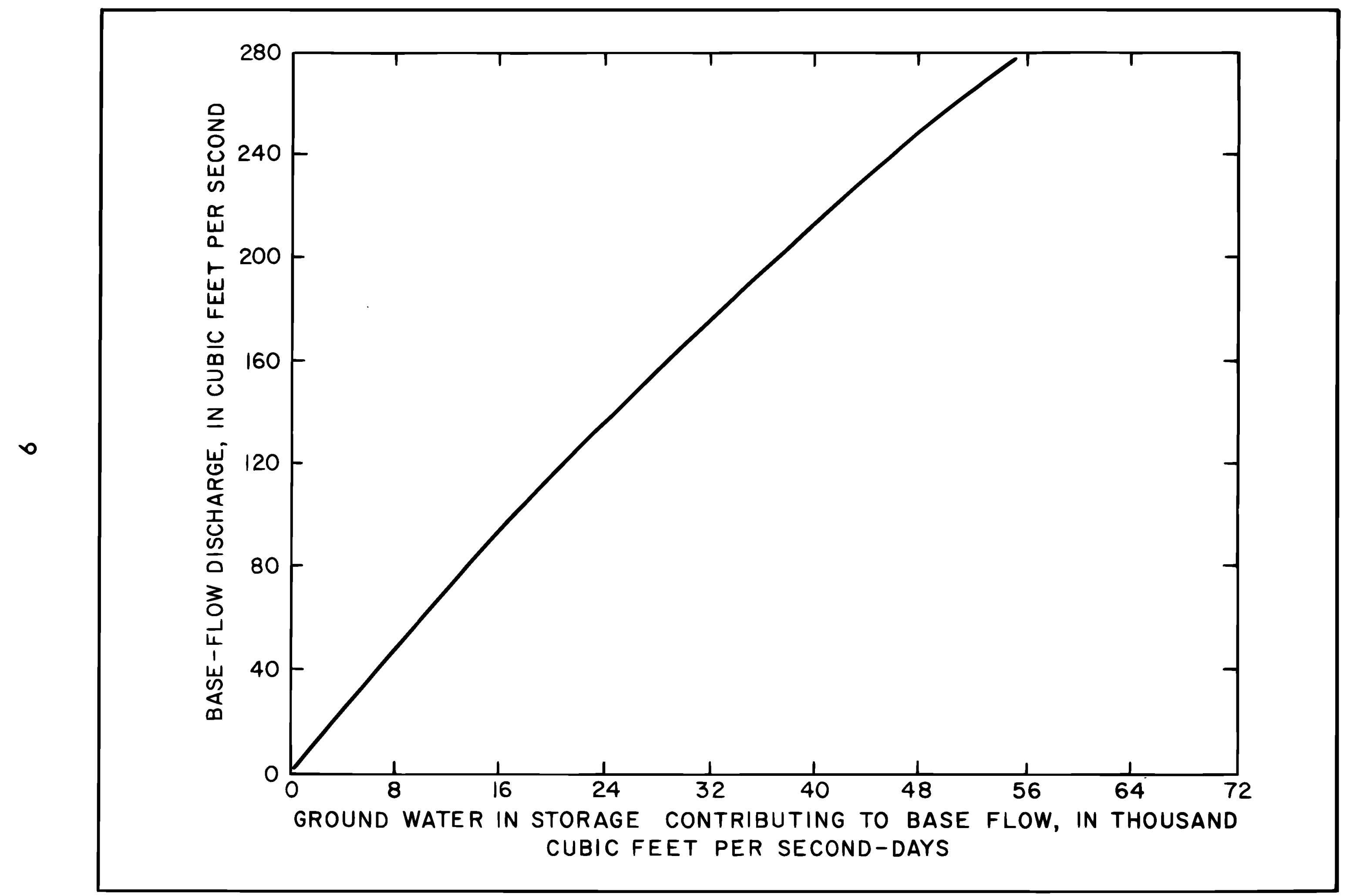

FIGURE4.-Relationship between the base flow of the Nueces River at Laguna and ground-water storage contributing to base flow in the Nueces River basin 


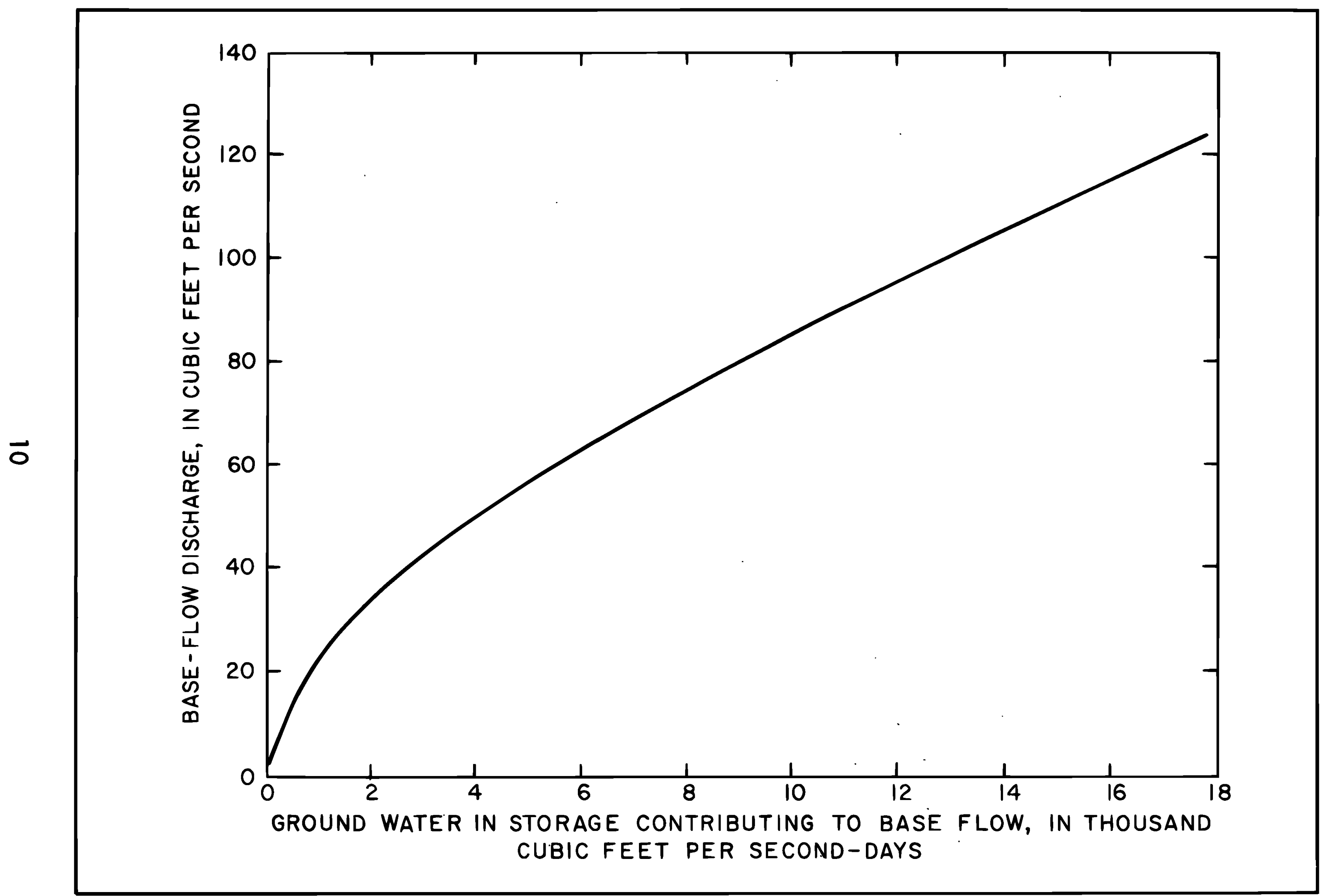

FIGURE 5.-Rolationship between the base flow of the Frio River at Concan and ground-water storage contributing to base flow in the Frio River basin 


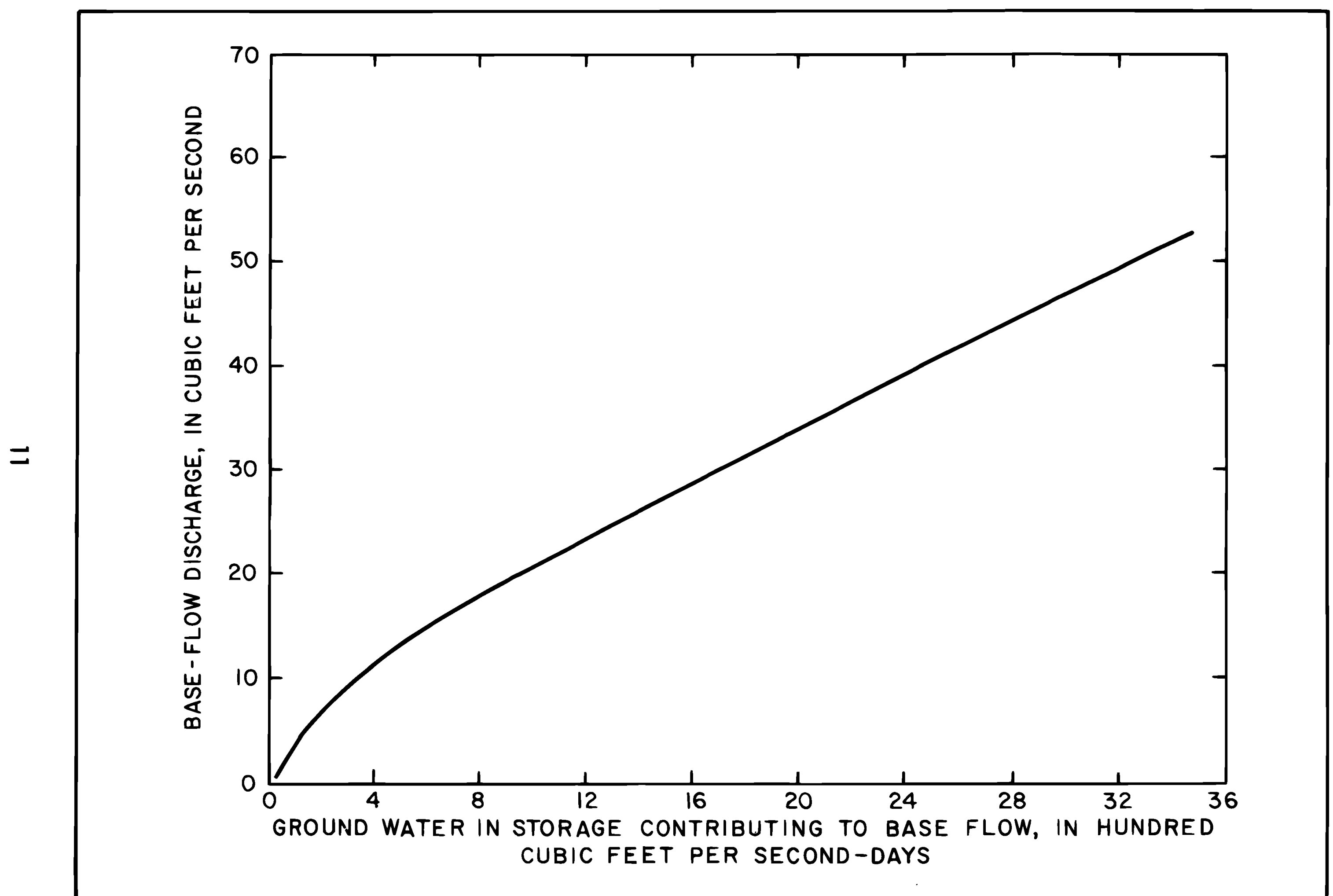

FIGURE 6.-Relationship between the base flow of the Dry Frio River near Reagan Wells and ground-water storage contributing to base flow in the Dry Frio River basin 


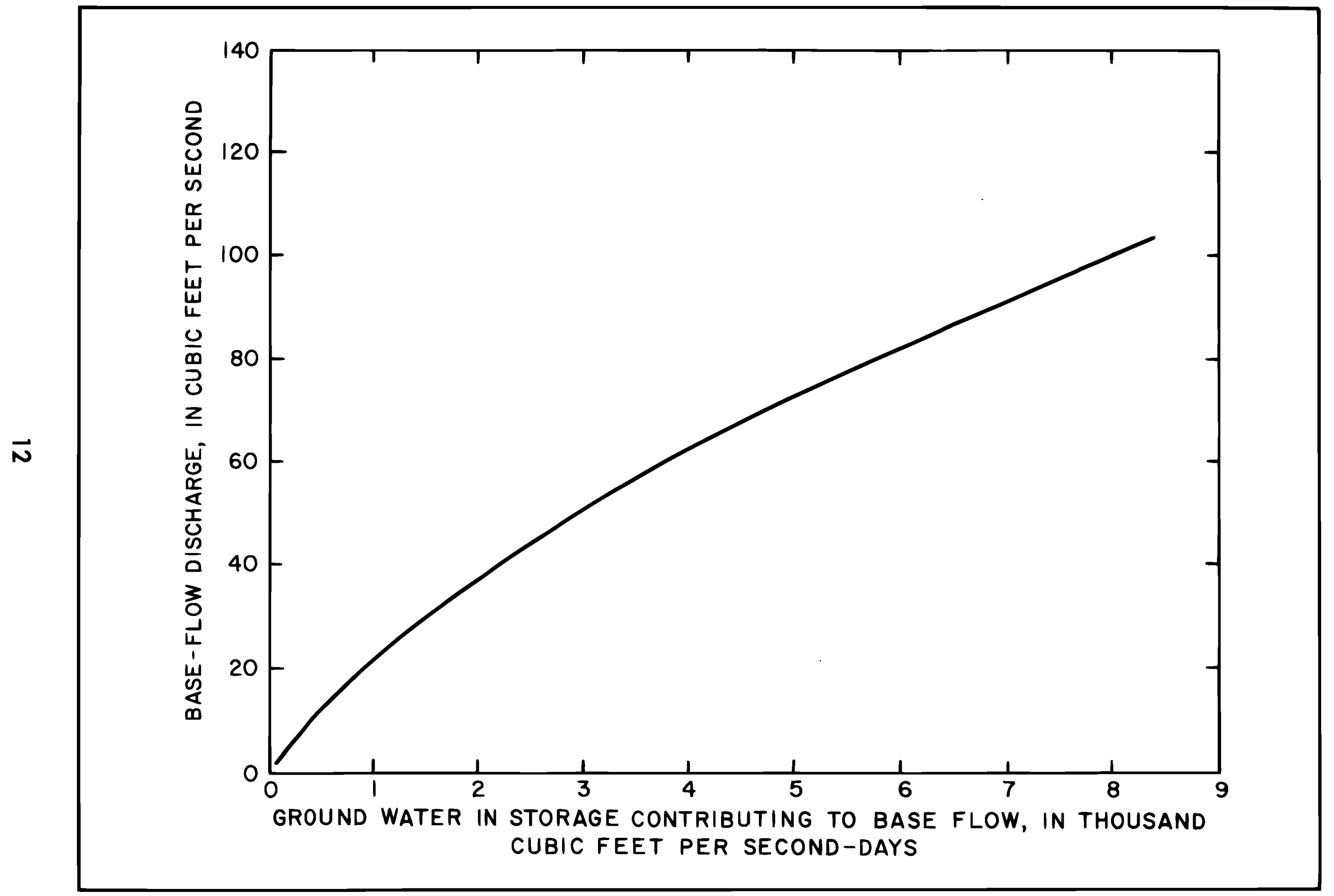

FIGURE 7.-Relationship between the base flow of the Sabinal River near Sabinal and ground-water storage contributing to base flow in the Sabinal River basin 


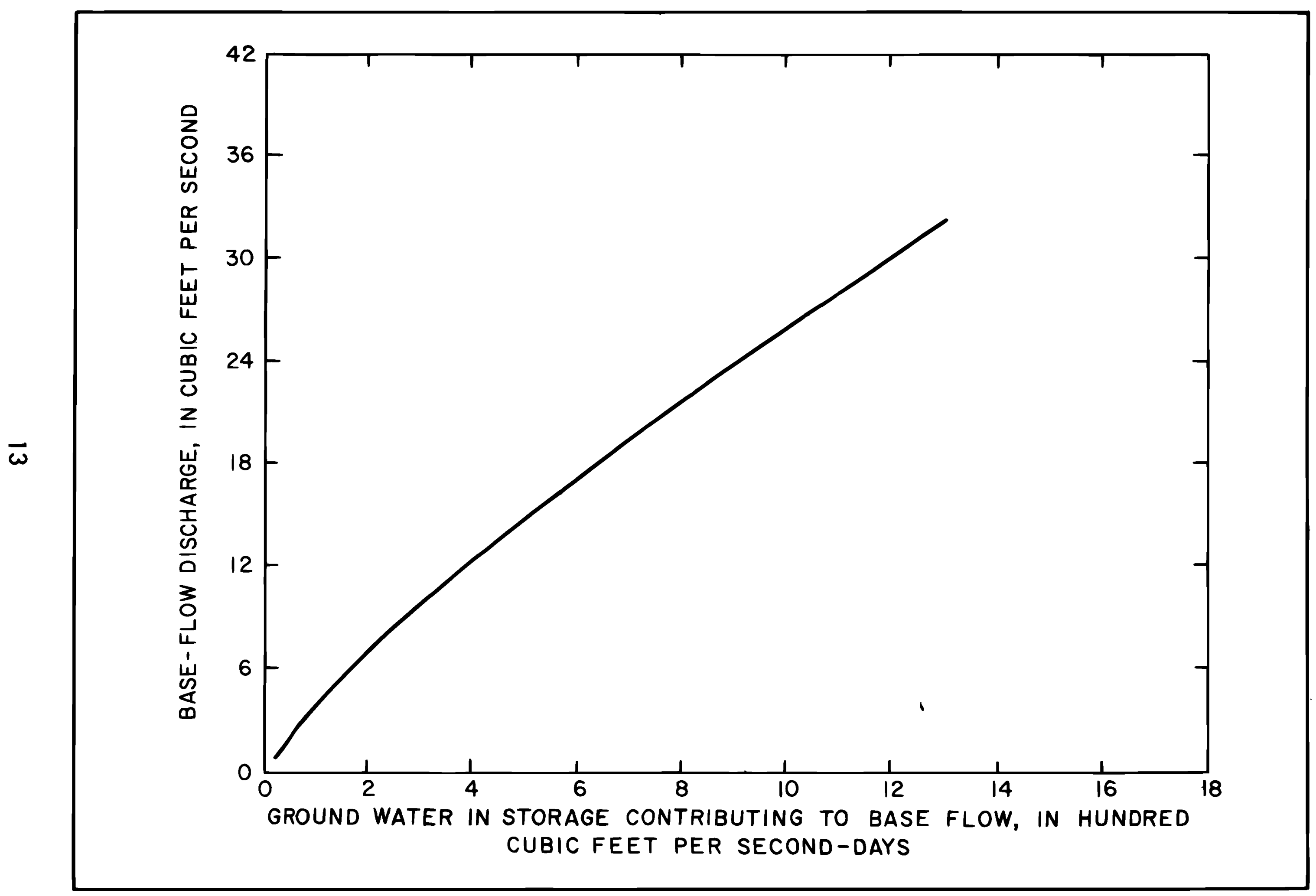

FIGURE 8.-Relationship between the base flow of Seco Creek at Miller Ranch near Utopia and ground-water storage contributing to base flow in the Secco Creek basin 


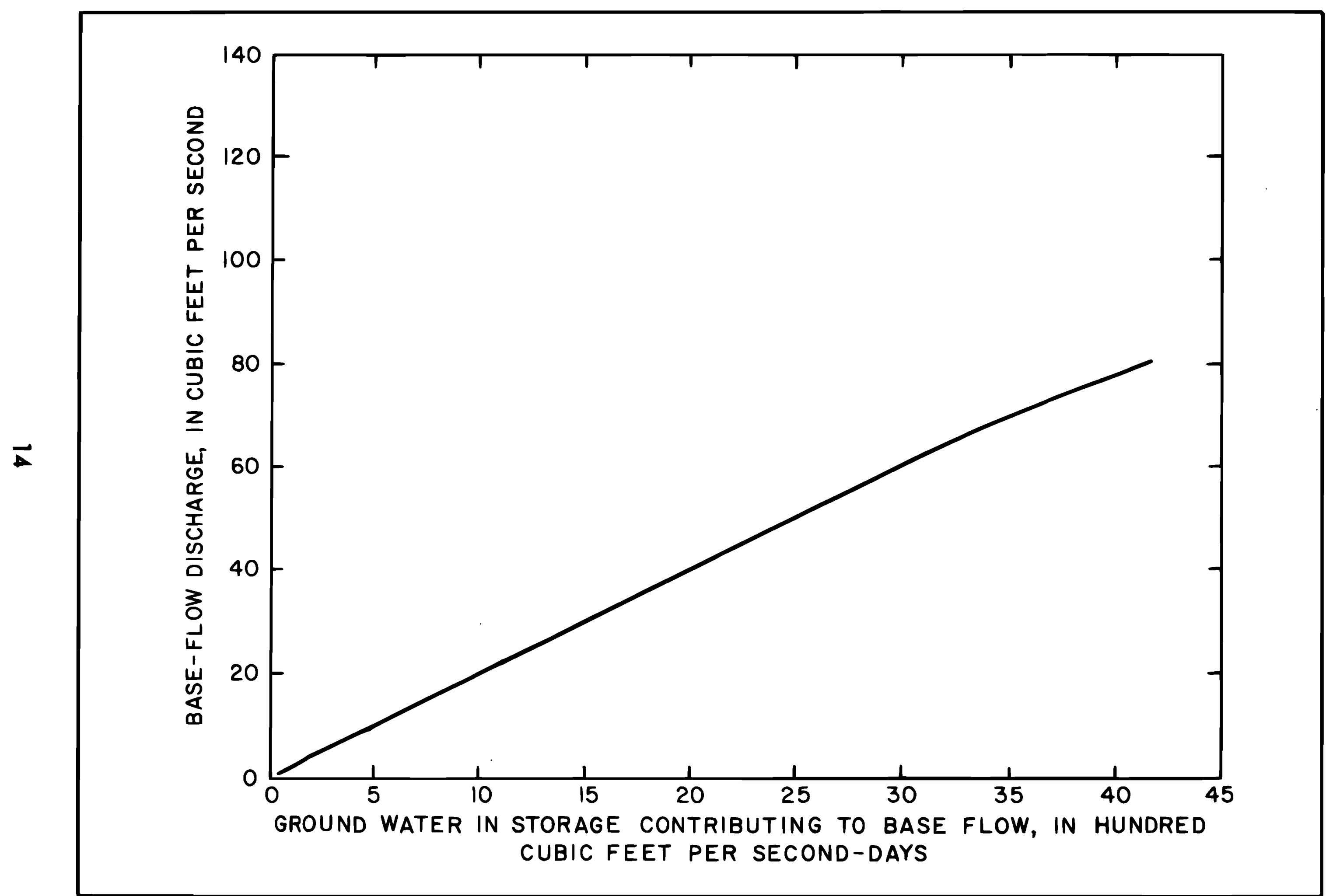

FIGURE 9.-Relationship between the base flow of Honde Creek near Tarpley and ground-water storage contributing to base flow in the Hondo Creek bosin 


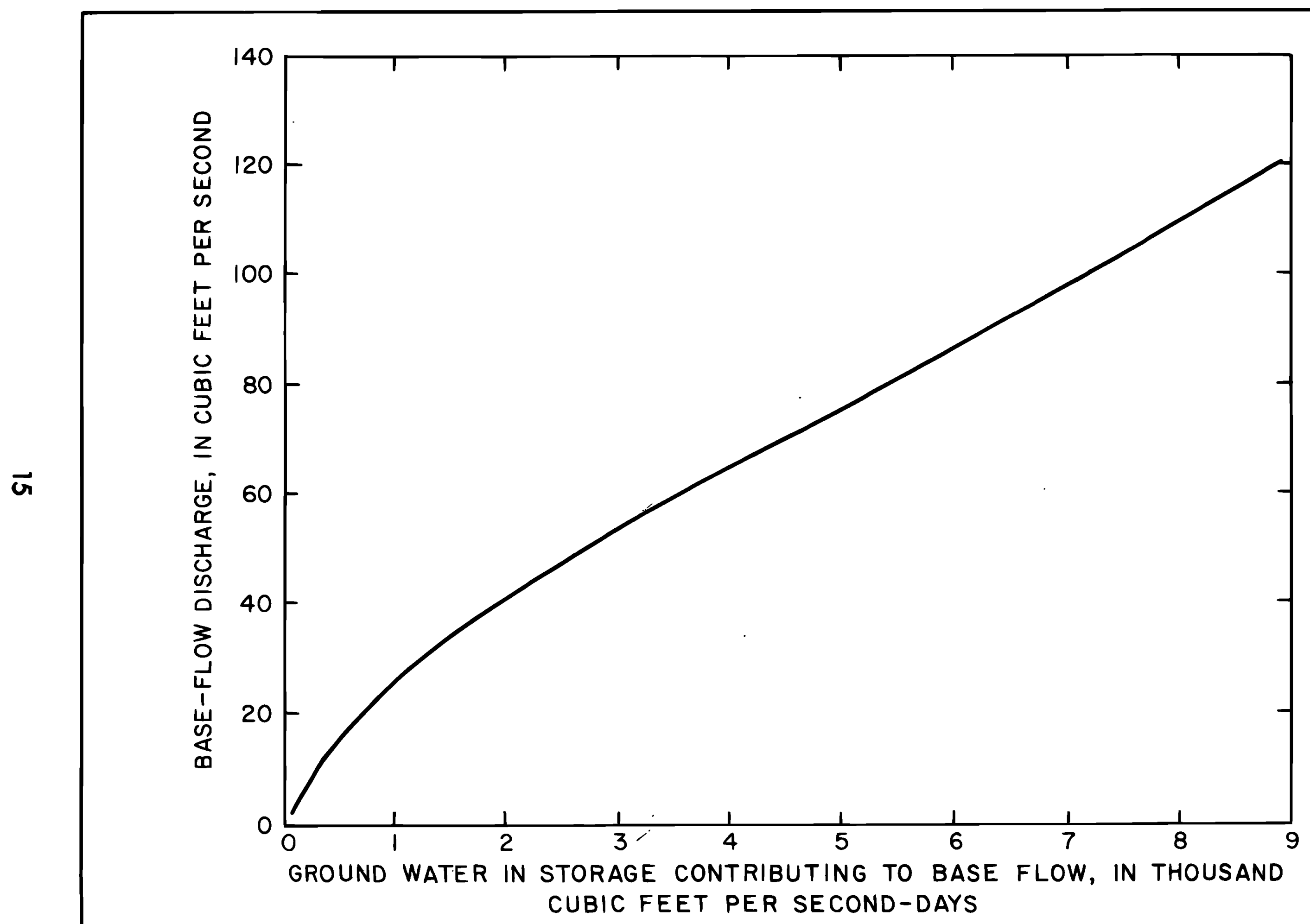

FIGURE 10.-Relationship between the base flow of the Blanco River at Wimberley and ground-water storage contributing to base flow in the Blanco River basin 
Miller Ranch near Utopia (fig. 8); Hondo Creek near Tarpley (fig. 9); and Blanco River at Wimberley (fig. 10). It should be noted that these graphs show storage in the Edwards Plateau aquifer between the upper and lower limits of base-flow discharge; total storage in the Edwards Plateau aquifer is not known.

Component (A), which is the initial increase in base flow after a storm, can be computed easily from the hydrograph (fig. 3) to determine all of the base flow contributed by a storm. Component (A) is equivalent to the volume encompassed within the empirical base-flow curve from the beginning of storm runoff (zero base-flow increase) to the point of maximum base-flow increase (point D, fig. 3). The lower boundary is an extrapolation of the previous base-flow recession curve to the same point in time (point E, fig. 3) as the maximum base-flow increase (point D, fig. 3).

The increment (DE) is the particular increase in base flow that is used to determine component (B) from graphs such as those on figures 4-10. The value of $Q t u$ for each individual storm in the area above the upper gaging station is the sum of components (A), (B), and (C).

\section{Adjustments for Distribution of Precipitation}

Runoff estimates related to determination of recharge in ungaged areas are based on the assumption that the runoff characteristics in these areas are similar to those in nearby or adjacent gaged areas. The available rainfall records are used to trace the distribution of rainfall for each major storm, and an adjustment to the estimated runoff is made when a wide variation occurs in the rainfall distribution.

The adjustment to the estimated unit runoff is based on a rainfall ratio that is determined from the average rainfall in each of the areas. The average rainfall is the arithmetic mean derived from records of the precipitation stations within each area. For example, gaged area $M$ receives an average rainfall of 5 inches during a storm; ungaged area $\mathrm{N}$ receives only 2 inches. The estimated unit runoff in area $\mathrm{N}$, based on the gaged unit runoff in area $M$, is adjusted by a rainfall ratio of $2 / 5$. When this ratio is plus or minus 20 percent of unity, which is an arbitrary designation, no adjustments are made for the distribution of rainfall.

Adjustments made on a "storm-by-storm" basis within an individual month have been compared with the adjustments made by using the total monthly rainfall data. The differences in the adjustments are small, probably because most of the precipitation occurs in storms of short duration. Large discrepancies may occur, however, when a rare storm of long duration overlaps into the following month. The computer program for estimating annual recharge was designed so that the adjustments for the distribution of precipitation are made monthly. 
The Nueces-West Nueces River basin is the westernmost basin that contributes recharge to the Edwards aquifer (fig. 1). The total inflow available for recharge includes the following: (1) All flow that passes the gaging station Nueces River at Laguna; (2) all flow that passes the gaging station West Nueces River near Brackettville; and (3) all estimated runoff from direct precipitation between these two upper gages and the gaging station on the Nueces River below Uvalde. Only floodflow passes the gage on the West Nueces River, and it is assumed that only this floodflow affects recharge to the aquifer extending south and east of the gaging station. The estimated runoff in the area between the upper gages and the lower gage is based on the contributions $\left(Q_{t u}\right)$ from individual storms in the gaged area above the gaging station Nueces River at Laguna. The total outflow is measured at the gaging station on the Nueces River below Uvalde.

Estimates of recharge to the Edwards aquifer in the Nueces-West Nueces River basin are made by use of a computer program containing the following equation:

$$
R_{n w n}=\left[Q_{n}+Q_{w n}+\left(S I_{n}\right)\left(R F_{n}\right)-Q_{n b u}\right](1.9835)
$$

where $R_{n w n}$ is the monthly recharge to the aquifer in the basin, in acrefeet;

$Q_{n}$ is the total monthly flow at the gaging station Nueces River at Laguna, in cfs-days;

Qwn is the total monthly flow at the gaging station West Nueces River near Brackettville, in cfs-days;

Qnbu is the total monthly flow at the gaging station Nueces River below Uvalde, in cfs-days;

$\mathrm{RF}_{\mathrm{n}}$ is the rainfall ratio obtained by the equation:

$$
R F_{n}=\frac{L P}{U P}
$$

where $L P$ is the average monthly precipitation in the area between the upper and lower gages, and

UP is the average monthly precipitation in the drainage area above the upper gage.

The computer program sets $\mathrm{RF}_{\mathrm{n}}$ equal to unity if the input value is between 0.8 and 1.2 .

$\mathrm{SI}_{\mathbf{n}}$ is the estimated monthly runoff, in cfs-days, in the area between the two upper gages and the lower gage (483 square miles). Runoff is assumed to be proportionate to the runoff in the drainage area (764 square miles) above the gage at Laguna. The calculation for $S I_{n}$ is as follows:

$$
S I_{n}=\frac{483}{764}\left(C_{n}+A_{n}+B_{n}\right)
$$


where $C_{n}$ is the floodflow or component (C), in cfs-days, that is obtained from analyses of the streamflow records at the Laguna gage.

$A_{n}$ is the initial increase in base flow during a flood, in cfs-days. It is the same as the base-flow component (A), which is obtained from the analyses of the streamflow records at the Laguna gage.

$B_{n}$ is the base-flow component (B), in cfs-days, which is obtained from the graph relating ground-water storage in the Edwards Plateau aquifer and the base flow at the Laguna gage (fig. 4).

Estimates of $\mathrm{SI}_{\mathrm{n}}$ are made only for the months in which significant storms occur. If a storm overlaps into the following month, the runoff is distributed proportionately according to the floodflow occuring during each month.

Frio-Dry Frio River Basin and Adjacent Areas

The procedure for estimating recharge in the Frio-Dry Frio River basin is similar to the procedure used for the Nueces-West Nueces River basin. Total inflow to the basin consists of the flow past the gaging stations Frio River at Concan and Dry Frio River near Reagan Wells, plus the estimated runoff resulting from precipitation in the area between these two gages and the gaging station Frio River below Dry Frio River near Uvalde (fig. 1). Total outflow from the infiltration area is measured at the gage on the Frio River below Dry Frio River near Uvalde.

The combined drainage area between the upper and lower gages, which is 139 square miles, is assumed to have the same runoff characteristics as the 522 square miles of combined drainage area above the gaging stations at Concan and Reagan Wells. The Leona River basin and the Blanco Creek basin are adjacent to the Frio-Dry Frio River basin on the west and east, respectively. The combined drainage area of these two small basins is 68 square miles and is included in the annual recharge estimates for the FrioDry Frio River basin. It is assumed that the recharge in this ungaged area is proportionate to the recharge in the Frio-Dry Frio River basin.

Estimates of annual recharge to the Edwards aquifer in the Frio-Dry Frio River basin, including the Leona River and Blanco Creek basins, are made by use of a computer program containing the following equation:

$$
R_{f d f}=\left[Q_{f}+Q_{d f}+\left(S_{f d f}\right)\left(R F_{f}\right)-Q_{f b d f}\right](1.9835)
$$

where $R_{f d f}$ is the monthly recharge to the aquifer in the basin, in acrefeet;

$Q_{f}$ is the total monthly flow at the gaging station Frio River at Concan, in cfs-days;

Qdf is the total monthly flow at the gaging station Dry Frio River near Reagan Wells, in cfs-days;

Qfbdf is the total monthly flow at the gaging station Frio River below Dry Frio River near Uvalde, in cfs-days; 
$\mathrm{RF}_{\mathrm{f}}$ is the rainfall ratio, obtained by use of the same equation given in the preceding discussion of the Nueces-West Nueces River basin; and

SIfdf is the estimated monthly runoff, in cfs-days, in the area between the upper gages and the lower gage, which is calculated as follows:

$$
S I_{f d f}=\frac{139}{522}\left(C_{f}+A_{f}+B_{f}+C_{d f}+A_{d f}+B_{d f}\right) .
$$

The parameters, $C_{f}, A_{f}$, and $B_{f}$ are the components (C), (A), and (B), respectively, as determined from hydrograph data from the gaging station Frio River at Concan. The parameters $C_{d f}, A_{d f}$, and $B_{d f}$ are components (C), (A), and (B), respectively, and are determined from hydrograph data from the gaging station Dry Frio River near Reagan Wells. Figures 5 and 6 show the relations between base flow and aquifer storage that were used in deriving the values of $B_{f}$ and $B_{d f}$.

Recharge in the ungaged adjacent areas (Leona River and Blanco Creek basins) is estimated only when floodflows occur. Streamflow records from the outflow (lower) gage near Uvalde indicate that only large storms result in runoff exceeding recharge in the infiltration area of the Frio-Dry Frio River basin; it is assumed that a proportionate amount of runoff occurs in the infiltration area of the adjacent basins. Recharge in these ungaged areas is assumed to be proportional to the recharge as computed for the Frio-Dry Frio River basin. The recharge in the adjacent areas is estimated to be 68/637 of the recharge in the Frio-Dry Frio River basin because this is the ratio of the drainage areas above the lower edge of the infiltration area. When flow at the lower gage $\left(Q_{f b d f}\right)$ is greater than zero, the equation used to compute the adjacent-area recharge ( $\left.R_{f a a}\right)$ is as follows:

$$
R_{\text {faa }}=\frac{68}{637}\left(R_{f d f}\right)
$$

Many storms that produce floodflows in this basin are not large enough to produce flow at the lower gage. When flow does not occur at the lower gage, recharge in the adjacent areas is included as part of the estimated runoff resulting from precipitation in the infiltration area of the FrioDry Frio River basin. Under these conditions, equation (2) is modified by increasing the area between the upper gages and the lower gage to account for the infiltration area of the ungaged areas. The equation used is as follows :

$$
R_{f d f}=\left[Q_{f}+Q_{d f}+\left(S_{f d f}\right)^{\prime}\left(R F_{f}\right)-Q_{f b d f}\right](1.9835)
$$

where

$$
\left(S I_{f d f}\right)^{\prime}=\frac{207}{522}\left(C_{f}+A_{f}+B_{f}+C_{d f}+A_{d f}+B_{d f}\right) \text {. }
$$




\section{Sabinal River Basin and Adjacent Areas}

The procedure for estimating recharge in the Sabinal River basin and the adjacent ungaged areas is similar to the procedure used in the previously described basins. Inflow is measured by the upper gage, Sabinal River near Sabinal; outflow is measured by the lower gage, Sabinal River at Sabinal (fig. 1).

The drainage area between the upper and lower gages is 41 square miles, of which the infiltration area comprises 15 square miles. It has been assumed that the area between the gages has the same runoff characteristics as the area (206 square miles) above the upper gaging station. The equation for computing recharge in the Sabinal basin is as follows:

$$
R_{s b}=\left[Q_{s n s}+\left(S_{s n s}\right)\left(R F_{s}\right)-Q_{s a s}\right](1.9835)
$$

where $R_{s b}$ is the monthly recharge to the aquifer in the basin, in acre-feet;

Qsns is the total monthly flow at the gaging station Sabinal River near Sabinal, in cfs-days;

Qsas is the total monthly flow at the gaging station Sabinal River at Sabinal, in cfs-days;

$\mathrm{RF}_{\mathrm{S}}$ is the rainfall ratio, obtained by use of the same equation given in the preceding discussion of the Nueces-West Nueces River basin; and

$\mathrm{SI}_{\text {sns }}$ is the estimated monthly runoff, in cfs-days, in the area between the upper and lower gages, which is calculated as follows:

$$
\mathrm{SI}_{\text {sns }}=\frac{41}{206}\left(\mathrm{C}_{\text {sns }}+\mathrm{A}_{\text {sns }}+\mathrm{B}_{\text {sns }}\right)
$$

The parameters ( $C_{\text {sns }}, A_{s n s}$, and $B_{s n s}$ ) are the hydrograph components (C), (A), and (B), respectively, as determined from streamflow data plus the storage-discharge relation shown on figure 7.

Twenty-four square miles in the infiltration area adjacent to the Sabinal River basin are drained by parts of Little Blanco, Nolton, and Ranchero Creeks. Recharge in this small area is assumed to be proportional to recharge in the Sabinal River basin and is included as part of the total recharge in the Sabinal basin. The following equation was used to estimate recharge to this adjacent area:

$$
R_{\text {sba }}=\frac{2.4}{41}\left(S I_{\text {sns }}\right)\left[\frac{R_{\text {sb }}}{Q_{\text {sns }}+\frac{15}{41}\left(S I_{\text {sns }}\right)}\right]
$$

where $R_{\text {sba }}$ is the monthly recharge to the adjacent area, in acre-feet, and all other terms are as described previously. 
The item expressed in brackets in the equation is a ratio of the recharge in the Sabinal River basin to the total available inflow (measured flow plus estimated runoff) above the infiltration area. Occasionally, during minor floods, this recharge ratio exceeds slightly the value of 1.00 , probably because the errors in the estimated runoff (SI sns $_{\text {) }}$ are large in relation to the quantity of flow. The computer program is designed so that this ratio is set to 1.00 when this condition occurs.

\section{Area Between the Sabinal River Basin and the Medina River Basin}

This area includes the drainage basins of the Seco Creek, Hondo Creek, and an ungaged area of 152 square miles between the Hondo Creek and Medina River basins that are drained by Verde and Quihi Creeks and their tributaries. Recharge in the Seco Creek and the Hondo Creek basins is estimated by using the same basic approach as previously explained. In the Seco Creek basin, inflow is measured at the upper gage, Seco Creek at Miller Ranch near Utopia (fig. 1), and outflow is measured at the lower gage, Seco Creek at Rowe Ranch near D'Hanis (fig. 1). The runoff for the 125-square-mile area between the upper and lower gages in the Seco Creek basin is assumed to be proportional to the runoff in the 43-square-mile area above the upper gaging station. The recharge equation used for the Seco. Creek basin is as follows:

$$
\mathrm{R}_{\mathrm{SC}}=\left[\mathrm{Q}_{\mathrm{su}}+\left(\mathrm{SI}_{\mathrm{su}}\right)(\mathrm{RF})-\mathrm{Q}_{\mathrm{sd}}\right](1.9835)
$$

where $R_{S C}$ is the monthly recharge, in acre-feet;

$\overline{Q s u}$ is the total monthly flow at the gaging station Seco Creek at Miller Ranch near Utopia, in cfs-days;

Qsd is the total monthly flow at the gaging station Seco Creek at Rowe Ranch near D'Hanis, in cfs-days;

$\underline{R F}$ is the rainfall ratio; and

$\mathrm{SI}_{\text {su }}$ is the estimated monthly runoff, in cfs-days, in the area between the upper and lower gages in the Seco Creek basin, which is computed as follows:

$$
S I_{s u}=\frac{125}{43}\left(C_{s u}+A_{s u}+B_{s u}\right)
$$

The parameters $C_{s u}, A_{s u}$, and $B_{s u}$ are the components $(C),(A)$, and (B), respectively, that were derived from the separation analysis of the daily streamflow hydrograph (Seco Creek at Miller Ranch near Utopia) plus the storage-discharge relation shown on figure 8.

Inflow in the Hondo Creek basin is measured by the upper gage, Hondo Creek near Tarpley (fig. 1); and outflow is measured by the lower gage, Hondo Creek at King Waterhole near Hondo (fig. 1). The runoff in the 56square-mile area between the upper and lower gages is assumed to be propor- 
tional to the runoff in the area of 86 square miles above the upper gaging station. The recharge equation for the Hondo Creek basin is as follows:

$$
R_{h}=\left[Q_{h t}+\left(S I_{h t}\right)\left(R F_{h}\right)-Q_{h h}\right](1.9835)
$$

where $R_{h}$ is the monthly recharge, in acre-feet;

Qht is the total monthly flow at the gaging station Hondo Creek near Tarpley, in cfs-days;

Qhh is the total monthly flow at the gaging station Hondo Creek at King Waterhole near Hondo, in cfs-days;

$\mathrm{RF}_{\mathrm{h}}$ is the rainfall ratio; and

$S I_{h t}$ is the estimated monthly runoff, in cfs-days, in the area between the upper and lower gages, which is calculated as follows:

$$
S I_{h t}=\frac{56}{86}\left(C_{h t}+A_{h t}+B_{h t}\right)
$$

The parameters $C_{h t}, A_{h t}$, and $B_{h t}$ are the components (C), (A), and (B), respectively, that were derived by the same procedures as described previously and by the use of the storage-discharge relation shown on figure 9.

An area of 12 square miles within the infiltration area adjacent to the Hondo Creek basin is drained by Parkers Creek and Live Oak Creek (fig. 1). Recharge in this small area is assumed to be proportional to recharge in the Hondo Creek basin. The following equation was used to estimate recharge in this adjacent area:

$$
\mathrm{R}_{\mathrm{ha}}=\frac{12}{56}\left(S I_{h t}\right)\left[\frac{\mathrm{R}_{\mathrm{h}}}{\mathrm{Qht}_{\mathrm{h}}+\frac{46}{56}\left(S I_{h t}\right)}\right]
$$

where $R_{h a}$ is the monthly recharge, in acre-feet, to the adjacent area; all other terms have been described previously.

The item expressed in brackets in the equation is a ratio of the recharge in the Hondo Creek basin to the total available inflow (measured flow plus estimated runoff) above the infiltration area. The 46 square miles represent the infiltration area within the 56 square miles of drainage area between the upper and lower gages in the Hondo Creek basin. During minor floods, this recharge ratio exceeds slightly the value of 1.00 , probably because the errors in the estimated runoff ( $\mathrm{SI}_{\mathrm{ht}}$ ) are large in relation to the quantity of flow. The computer program is designed to set this recharge ratio equal to 1.00 if this condition occurs.

The estimates of recharge for the large ungaged area (152 square miles) drained by Verde and Quihi Creeks (fig. 1) are based on runoff data obtained for the gaged areas of the Hondo Creek and Medina River basins. The units of surface runoff for the areas above the gage Hondo Creek near Tarpley and above the gage Medina River near Pipe Creek (fig. 1) are averaged and applied to the ungaged area. The recharge is esti- 
mated as a percentage of the computed runoff, and the basis used is the Hondo Creek recharge ratio. The equation for estimating the recharge in the ungaged area between the Hondo Creek and the Medina River is as follows:

$$
R_{h m}=152\left(\frac{\frac{Q_{h t}}{86}+\frac{Q_{m p c}}{474}}{2}\right)\left[\frac{R_{h}}{Q_{h t}+\frac{46}{56}\left(S I_{h t}\right)}\right]
$$

where $R_{h m}$ is the monthly recharge in the area between the Hondo Creek and the Medina River, in acre-feet; and

Qmpc is the monthly flow at the gaging station Medina River near Pipe Creek, in cfs-days.

All other terms in the equation have been described previously, including the Hondo Creek recharge ratio, the last item in brackets. The drainage area above the Tarpley gage is 86 square miles; the drainage area above the Pipe Creek gage is 474 square miles.

\section{Medina River Basin}

The procedure used for estimating recharge in the Medina River basin is different from the procedure used in other basins because streamflow in the basin is regulated by a large reservoir (fig. 1). Medina Lake, impounded by Medina Dam, is located over the infiltration area and seepage losses from the lake recharge the Edwards aquifer.

The basis for estimating recharge from Medina Lake is a correlation of reservoir stage and seepage into the aquifer. Lowry (1953) constructed two correlation curves, one representing seepage losses with a rising stage and the other representing losses with a falling stage. The curves are substantially different and apparently reflect the influence of bank storage.

The correlations were developed from data on streamflow, evaporation, and reservoir stage, and on inflow-outflow analyses that reflected water balances of the reservoir over a long period of time. A graph relating the month1y average contents of Medina Lake with the seepage losses to the Edwards aquifer is shown on figure 11. This graph also reflects the losses from Diversion Reservoir (4 miles downstream from Medina Lake), which is used to divert water through an irrigation canal into southern Medina and Bexar Counties. Lowry (1953) estimated that when Diversion Reservoir is full or nearly full, a constant seepage of 1,500 acre-feet per month recharges the Edwards aquifer. Continuous leakage around and below Medina Dam has maintained Diversion Reservoir at near capacity except during periods of extended droughts.

Therefore, figure 11 was used to estimate monthly recharge to the Edwards aquifer in the Medina River basin. The average monthly contents in Medina Lake are derived from reservoir-stage records of the U.S. Geological Survey. These records are also used to determine whether reservoir stage is rising or falling. 


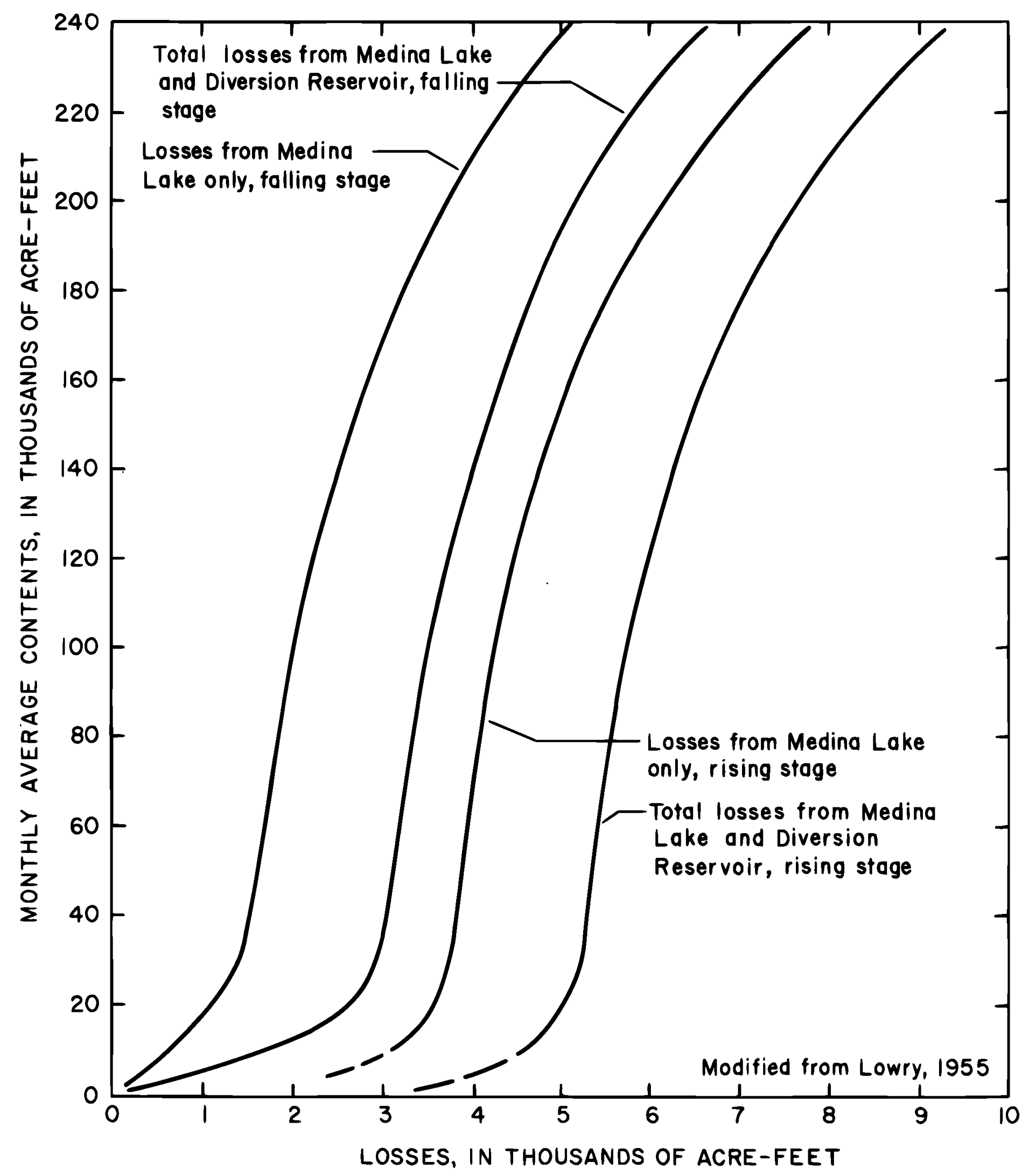

FIGURE II.-Relationship befween the monthly average content of Medina Lake and recharge to the Edwards oquifer from Medina Lake and Diversion Reservoir 


\section{Area Between the Medina River Basin and the Cibolo Creek Basin}

The drainage area between the Medina River and Cibolo Creek, and upstream from the lower edge of the infiltration area of the Edwards aquifer, is approximately 282 square miles, of which 131 square miles are in the infiltration zone. This area is partly drained by San Geronimo, Leon, and Salado Creeks, plus other smaller creeks and tributaries.

Much of the area is ungaged and recharge must be estimated by using data from adjacent basins. The gaging station Salado Creek at San Antonio (fig. 1) is used to measure the outflow from a drainage area of 137 square miles; the area above the lower edge of the infiltration area is 105 square miles and that above the upper edge of the infiltration area is 35 square miles. The infiltration area is 70 square miles, and the area between the gaging station and the lower edge of the infiltration area is 32 square miles. Runoff above the infiltration area in the Salado Creek basin is not measured directly because suitable gaging sites are not available. Therefore, estimates of total runoff to the area of upper Salado Creek are based on the assumption that the computed unit of runoff in the Cibolo Creek basin is applicable to this area. The recharge equation for the Salado Creek basin is as follows:

$$
R_{S}=137\left(U R_{C}\right)\left(R F_{S C}\right)-\left(Q_{S}\right)(1.9835)
$$

where $R_{S}$ is the monthly recharge to the aquifer, in acre-feet;

$U R_{c}$ is the unit of runoff in the Cibolo Creek basin, in acre-feet per square mile;

$Q_{s}$ is the total monthly flow at the gaging station Salado Creek at San Antonio, in cfs-days; and

$\mathrm{RF}_{\mathrm{SC}}$ is the ratio of average rainfall in the Salado Creek basin to average rainfall in the Cibolo Creek basin.

The estimate of total inflow to the remaining 177 square miles of ungaged area is based on an average unit of runoff as derived from the unit of runoff at the gaging station Medina River near Pipe Creek and the unit of runoff computed for the Cibolo Creek basin. It is also assumed that the ratio of recharge in the Salado Creek basin to the total inflow above and within the infiltration area is applicable to the ungaged area. The recharge equation for this ungaged area is as follows:

$$
R_{m s}=177\left[\frac{\left(\frac{Q_{m p c}}{474}\right)(1.9835)+U R_{c}}{2}\right]\left[\frac{R_{s}}{105 U R_{c} R F_{S c}}\right]
$$

where $R_{m s}$ is the monthly recharge in the area between Medina River and Salado Creek, in acre-feet.

All other terms and drainage areas in the equation have been identified previously. The first bracketed item represents the average unit of runoff derived from streamflow records from the gaging station Medina River near 
Pipe Creek and the unit of runoff for the Cibolo Creek basin. The second bracketed item is the ratio of recharge in the Salado Creek basin to the total available inflow above the lower edge of the infiltration area.

The total recharge for the area between the Medina River basin and the Cibolo Creek basin is the sum of $R_{S}$ and $R_{m s}$.

\section{Cibolo Creek and Dry Comal Creek Basins} Cibolo Creek Basin

Streamflow in the Cibolo Creek basin is measured at the gaging stations Cibolo Creek near Boerne and Cibolo Creek at Selma (fig. 1). Runoff from the uppermost 68 square miles of the Cibolo Creek basin is measured at the gage near Boerne. The gage near Selma, which is downstream from the lower edge of the infiltration area, has a drainage area of 274 square miles, of which 19 square miles are within the infiltration area.

At one time, a gaging station just upstream from the infiltration area was installed to measure all inflow to the infiltration area. However, considerable streamflow losses occurred in the Glen Rose Formation upstream from this gage, which precluded assessing the unit of runoff for inflow analyses. This gage was removed and reestablished near Boerne. The Glen Rose Formation along and near the Cibolo Creek is highly permeable in the shallow subsurface, and a substantial part of the runoff of Cibolo Creek infiltrates this section and is assumed to move laterally into the Edwards aquifer.

Runoff in the adjacent Guadalupe River basin is gaged by streamflow stations at Comfort and at a site near Spring Branch (fig. 1). Runoff in the large drainage area between these gages provides a basis for computing the unit of runoff that may be applicable to the Cibolo Creek basin on and above the infiltration area.

The distribution of average precipitation in the Cibolo Creek basin and in the Guadalupe River basin between the two gages can be derived from the records of several precipitation stations in these areas. The average monthly precipitation has been used (1) to select the unit of runoff applicable to the Cibolo Creek basin $\left(U R_{c}\right)$ from either the unit of runoff for the Guadalupe River basin ( $U R_{g}$ ) or the unit of runoff as derived from the area above the gage Cibolo Creek near Boerne (UR $c b$ ), and (2) to adjust the selected unit of runoff by use of an appropriate rainfall ratio.

The computer program has been designed so that the selection of the unit of runoff of the representative basin is as follows: (1) The difference $(J)$ between the average rainfall in the Cibolo Creek basin above the gaging station at Selma and the average rainfall in the upper Cibolo Creek basin (above the gage near Boerne) is determined; (2) the difference (K) between the average rainfall in the Cibolo Creek basin above the gaging station at Selma and the average rainfall in the Guadalupe River basin 
above the gaging station at Sattler is determined; (3) if (J) is equal to or greater than $(K)$, the value of $U R_{g}$ is selected; and (4) if (J) is smaller than $(K)$, the value of $U R_{c b}$ is selected.

Recharge in the Cibolo Creek basin is computed by use of the following equation:

$$
R_{c}=274\left(U_{c}\right)\left(R F_{C}\right)-\left(Q_{c s}\right)(1.9835)
$$

where $R_{c}$ is the monthly recharge in the Cibolo Creek basin, in acre-feet;

$U R_{C}$ is the unit of runoff in the Cibolo Creek basin, in acre-feet per square mile;

$R_{C}$ is the rainfall ratio that relates average rainfall in the Cibolo Creek basin on and above the infiltration area to the average rainfall on the area of known runoff; and

Qcs is the total monthly flow at the gaging station Cibolo Creek at Selma, in cfs-days.

$$
\begin{aligned}
& U R_{c}=U R_{g} \text { or } U R_{c b} \\
& U R_{g}=\left[\frac{Q_{g s p}-Q_{g c}}{477}\right] \\
& U R_{c b}=\left(\frac{Q_{c b}}{68}\right)(1.9835)
\end{aligned}
$$

where $U R_{g}$ is the unit of runoff in the Guadalupe River basin, in acre-feet per square mile;

$\mathrm{UR}_{\mathrm{cb}}$ is the unit of runoff in the Cibolo Creek basin near Boerne, in acre-feet per square mile;

Qgsp is the total monthly flow at the gaging station Guadalupe River near Spring Branch, in cfs-days;

Qgc is the total monthly flow at the gaging station Guadalupe River at Comfort, in cfs-days; and

$\mathrm{Qcb}_{\mathrm{cb}}$ is the total monthly flow at the gaging station Cibolo Creek near Boerne, in cfs-days.

The Guadalupe River drains 477 square miles between the gage at Comfort and the gage near Spring Branch. The drainage area of the Cibolo Creek basin above the gage near Boerne is 68 square miles.

\section{Dry Comal Creek Basin}

The outflow of Dry. Comal Creek (fig. 1) is measured at the gaging station Comal River at New Braunfels. The drainage area above the gage is 130 square miles; the infiltration area consists of the upper 89 square miles, which is not gaged. The discharge of Comal Springs at New Braunfels flows into Dry Coma1 Creek above the gaging station, and the measured flow is adjusted to determine the runoff from Dry Comal Creek. The Comal River is the short channel distance between Comal Springs and Dry Comal Creek. 
Runoff in the Dry Comal Creek basin above the gaging station Comal River at New Braunfels is computed by applying the unit of runoff derived from measured streamflow on the Guadalupe River between the gage at Sattler and the gage at New Braunfels (fig. 1). Contributions to the Guadalupe River from Hueco Springs, situated upstream from the gage Guadalupe River above Comal River at New Braunfels (fig. 1), are accounted in the computa$t i o n$ of the unit of runoff in the area between the gages. The equation for estimating recharge in the Dry Comal Creek basin is as follows:

$$
R_{d c}=\left[130\left(\frac{Q_{g n b}-Q_{g s}-Q_{h s}}{82}\right)\left(R_{d}\right)-\left(Q_{c n b}-Q_{c o s}\right)\right]
$$

where $R_{d c}$ is the monthly recharge in the Dry Comal Creek basin, in acrefeet.

Qgnb is the total monthly flow measured at the gaging station Guadalupe River above Comal River at New Braunfels, in cfs-days.

Qgs is the total monthly flow measured at the gaging station Guadalupe River at Sattler, in cfs-days. The Guadalupe River drains 82 square miles between the gage at Sattler and the gage at New Braunfels.

Qhs is the total monthly flow of Hueco Springs, in cfs-days. The springflow is estimated from monthly spring-flow measurements.

$Q_{c n b}$ is the total monthly flow measured at the gaging station Comal River at New Braunfels, in cfs-days.

Qcos is the total monthly flow of Comal Springs, separated from the measurements at the gaging station Comal River at New Braunfels, in cfs-days.

$R F_{d}$ is the rainfall ratio of the average rainfall in the Dry Comal Creek basin to the average rainfall in the Guadalupe River basin between the gages at Sattler and at New Braunfels.

\section{Guadalupe River Basin}

The Guadalupe River crosses the infiltration area of the Edwards aquifer (fig. 1), but does not contribute recharge in significant quantities. Although 48 square miles of area in the Guadalupe River basin is within the infiltration area, seepage studies indicate that the net streamflow losses and gains in the area are small and insignificant. The potentiometric surface of the aquifer in the New Braunfels area is generally at the level of the streambed of the Guadalupe River and is relatively stable because of the large and almost perennial flow of Comal Springs.

\section{Blanco River Basin and Adjacent Area}

Recharge in the Blanco River basin, the easternmost basin in the infiltration area, is estimated by using the same procedure as used in the Nueces River basin. 
Inflow is composed of the flow past the upper gaging station Blanco River at Wimberley, and outflow is measured by the gaging station Blanco River near Kyle. Total runoff in the 57-square-mile area between the upper gage and the lower gage is determined by assuming that the area has the same runoff characteristics as the 355-square-mile area above the upper gage. The equation for estimating recharge in the Blanco River basin is as follows:

$$
\mathrm{R}_{\mathrm{b}}=\left[\mathrm{Q}_{\mathrm{bw}}+\left(\mathrm{SI}_{\mathrm{bw}}\right)\left(\mathrm{RF}_{\mathrm{b}}\right)-\mathrm{Q}_{\mathrm{bk}}\right](1.9835)
$$

where $R_{b}$ is the monthly recharge in the Blanco River basin, in acre-feet;

Qbw is the total monthly flow measured at the gaging station Blanco River at Wimberley, in cfs-days;

Qbk is the total monthly flow measured at the gaging station Blanco River near Kyle, in cfs-days;

$\mathrm{RF}_{\mathrm{b}}$ is the rainfall ratio of the average rainfall in the area between the two gages to the average rainfall in the area above the Wimberley gage; and

$S I_{b w}$ is the estimated monthly runoff, in cfs-days, in the area between the upper and lower gage, which is computed as follows:

$$
S_{I_{b w}}=\frac{57}{355}\left(C_{b w}+A_{b w}+B_{b w}\right)
$$

The parameters $\mathrm{C}_{\mathrm{bw}}, \mathrm{A}_{\mathrm{bw}}$, and $\mathrm{B}_{\mathrm{bw}}$ are equivalent to the $(\mathrm{C}),(\mathrm{A})$, and (B) components, respectively, determined from the separation analysis of the daily streamflow hydrograph and the storage-discharge graph (fig. 10) for the Blanco River at Wimberley.

At some places in the infiltration area, the Blanco River has eroded deeply into the outcrop of the Edwards Limestone. During times when the aquifer head is high, the aquifer accepts little recharge and at other times may discharge to the river. The computer program is designed so that when the measured outflow exceeds the estimated inflow, the estimated recharge is zero. Under these conditions, the water-balance equation will indicate a discharge from the aquifer to the river.

The area between the Guadalupe River basin and the Blanco River basin is an ungaged area of 94 square miles within the infiltration area, which is drained by Sink, Purgatory, York, and Alligator Creeks. This area is surrounded by the following gaged drainage areas: The Blanco River basin above the Wimberley gage; the Guadalupe River basin between the Sattler and New Braunfels gages; and the Plum Creek basin above the gage at Lockhart (fig. 1).

Inflow to this area is estimated from the average of the units of runoff derived from (1) the runoff at the gage Blanco River at Wimberley, (2) the runoff in the Guadalupe River basin between the Sattler and New Braunfels gages (adjusted for the flow of Hueco Springs), and (3) runoff 
at the gage Plum Creek at Lockhart. Outflow from this area is assumed to be proportional to the outflow from the infiltration area in the Dry Comal Creek basin. Recharge in this ungaged area, termed as adjacent to the Blanco River basin, is the difference between the estimated inflow on and above the infiltration area and the estimated outflow below the infiltration area.

The equation for estimating recharge in the area adjacent to the Blanco River basin is expressed as follows:

$$
R_{b a}=94\left[\frac{\left(\frac{Q_{b w}}{355}\right)+\left(\frac{Q_{g n b}-Q_{g s}-Q_{h s}}{82}\right)+\left(\frac{Q_{p} 1}{112}\right)}{3}-\left(\frac{Q_{c n b}-Q_{c o s}}{130}\right)\right]
$$

where $R_{b a}$ is the monthly recharge, in acre-feet; and

$\mathrm{Qpl}_{\mathrm{p}}$ is the total monthly flow measured at the gaging station Plum Creek at Lockhart, in cfs-days. The drainage area above the Lockhart gage is 112 square miles. The other variables in equation (13) have been defined in the sections describing recharge in the Blanco River basin and the Dry Comal Creek basin.

\section{CONCLUSIONS}

The method described in this report for estimating annual recharge to the Edwards aquifer is basically the same method used by various investigators who have made recharge estimates dating back to 1934 . Table 1 shows the estimated annual recharge to the Edwards aquifer by basin from 1934 to 1975. Recharge estimates made since 1953 are considered to be more accurate because gaging stations were installed after 1953 in several areas that were previously ungaged.

Errors in the estimates of recharge are the results of inaccuracies in streamflow measurements in gaged areas and of discrepancies in runoff estimates in ungaged areas. The errors in streamflow measurements are minor, because most of the records in the San Antonio area are regarded by the U.S. Geological Survey as "excellent," which means that about 95 percent of the daily discharges are accurate within 5 percent. Some estimates of runoff in ungaged areas, which represent about 30 percent of the infiltration area, may have large errors for individual storms.

Occasionally, the water-balance equations used for computed recharge are complicated by the occurrence of heavy rainstorms in the infiltration area and in areas between the lower edge of the infiltration area and the lower gaging stations. In some of the computations, the outflow at the lower gage may be greater than the inflow at the upper gage. Under these conditions, the recharge is assumed to be zero only during certain times in the Blanco River basin, where high aquifer-head conditions produce discharge from the aquifer. In all other basins, estimates of runoff are 


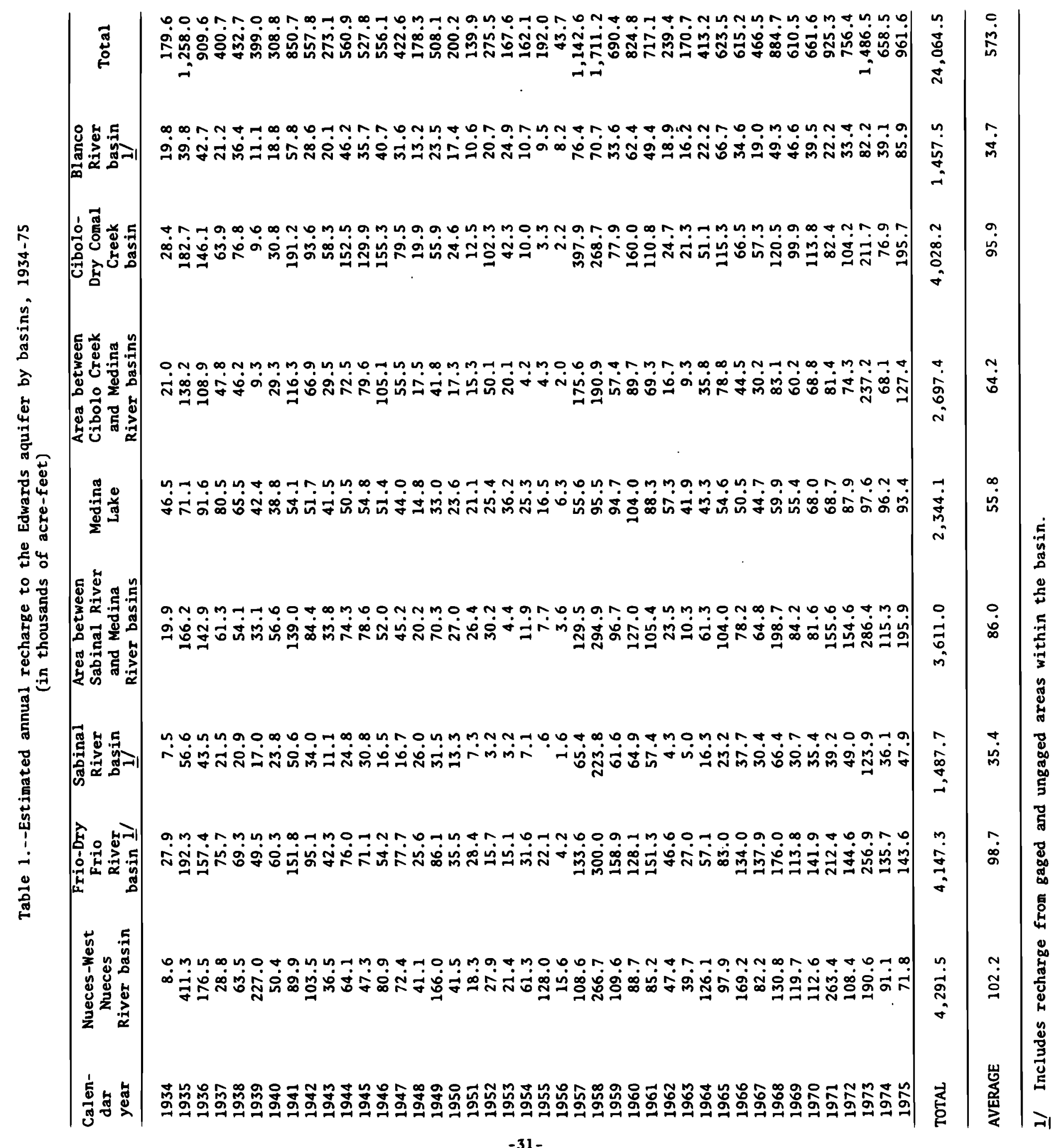


adjusted to reflect the heavy rainfall in the area between the upper and lower gages. The long-term average estimate of annual recharge is probably representative of the true average, because the averaging procedure of the many estimates tends to cancel out the major errors. The inflow-outflow analyses made by Garza $(1962,1966)$ indicate that the methods of estimating recharge are adequate in assessing long-term recharge and the annual average recharge over a long period. Monthly estimates of recharge during periods of high runoff probably contain the major errors.

The FORTRAN IV computer program developed for computing recharge to the Edwards aquifer in the San Antonio area is not included in this report, but is available from the U.S. Geological Survey upon request. 


\section{SELECTED REFERENCES}

Garza, Sergio, 1962, Recharge, discharge, and changes in ground-water storage in the Edwards and associated limestones, San Antonio area, Texas, a progress report on studies, 1955-59: Texas Board Water Engineers Bu11. 6201, 51 p. 1963, Records of precipitation, aquifer head, and ground-water recharge to the Edwards and associated 1imestones, 1960-62, San Antonio area, Texas: Edwards Underground Water Dist. Bull. 3, 7 p: 1964, Records of precipitation, aquifer head, and ground-water recharge to the Edwards and associated limestones, San Antonio area, Texas, 1963: Edwards Underground Water Dist. Bull. 6, 7 p. 1966, Ground-water resources of the San Antonio area, Texas, a progress report on studies, 1960-64: Texas Water Devel. Board Rept. 34, $36 \mathrm{p}$.

Guyton, W. F., and Associates, 1965, Report on recharge to the Edwards ground-water reservoir, 1962-63: Consulting ground-water hydrologist rept. to the San Antonio City Water Board, 22 p.

Lowry, R. L., 1953, Hydrologic report, Medina River above Applewhite Dam site: Consulting engineer rept. to the San Antonio City Water Board. 1955, Recharge to the Edwards ground-water reservoir: Consulting engineer rept. to San Antonio City Water Board.

Maclay, R. W., and Sma11, T. A., 1976, Progress report on the geology of the Edwards aquifer, San Antonio area, Texas, and preliminary interpretation of borehole geophysical and laboratory data on carbonate rocks: U.S. Geol. Survey Open-File Rept. 76-627, 65 p.

Maclay, R. W., and others, 1973, Hydrology of the Edwards Limestone aquifer: Geol. Soc. America Hydrogeology Field Trip, San Antonio, Texas, $16 \mathrm{p}$.

Petitt, B. M., Jr., and George, W. 0., 1956, Ground-water resources of the San Antonio area, Texas, a progress report on current studies: Texas Board Water Engineers Bull. 5608, v. 1, 85 p.

Puente, Celso, 1971, Records of precipitation, water levels, and groundwater recharge to the Edwards and associated limestones, San Antonio area, Texas, 1970: Edwards Underground Water Dist. Bu11. 27, 11 p. 1972 , Records of precipitation, water $1 \mathrm{evels,}$, and ground-water recharge to the Edwards and associated limestones, San Antonio area, Texas, 1971: Edwards Underground Water Dist. Bul1. 30, $11 \mathrm{p}$. 1973, Ground-water discharge from the Edwards and associated limestones, San Antonio area, Texas, 1972: Edwards Underground Water Dist. Bull. $31,8 \mathrm{p}$. 1974, Records of precipitation, water levels, and ground-water recharge to the Edwards and associated 1 imestones, San Antonio area, Texas, 1972-73: Edwards Underground Water Dist. Bul1. 33, $13 \mathrm{p}$. 1975, Relation of precipitation to annual ground-water recharge to the Edwards aquifer, San Antonio area, Texas: U.S. Geol. Survey Open-File Rept. 75-298, 31 p.

Rettman, P. L., 1966, Records of precipitation, aquifer head, and groundwater recharge to the Edwards and associated limestones, San Antonio area, Texas, 1965: Edwards Underground Water Dist. Bu11. 12, 8 p. 


\section{SELECTED REFERENCES--Continued}

1967, Records of precipitation, aquifer head, and ground-water recharge to the Edwards and associated limestones, San Antonio area, Texas, 1966: Edwards Underground Water Dist. Bu11. 15, 9 p. 1968 , Records of precipitation, aquifer head, and ground-water recharge to the Edwards and associated limestones, San Antonio area, Texas, 1967: Edwards Underground Water Dist. Bul1. 18, 9 p. 1969, Records of precipitation, aquifer head, and ground-water recharge to the Edwards and associated limestones, San Antonio area, Texas, 1968: Edwards Underground Water Dist. Bu11. 21, 9 p. 1970 , Records of precipitation, aquifer head, and ground-water recharge to the Edwards and associated limestones, San Antonio area, Texas, 1969: Edwards Underground Water Dist. Bul1. 24, 11 p.

Rose, P. R., 1972, Edwards Group, surface and subsurface, Central Texas: Univ. Texas, Bur. Econ. Geol. Rept. Inv. 74, 198 p.

Texas Board Water Engineers and U.S. Geological Survey, 1960, Channel gain and loss investigations, 1918-58: Texas Board Water Engineers Bull. 5807-D, 270 p.

U.S. Geological Survey, 1974, Water resources data for Texas, 1973; part 1, surface-water records: U.S. Geol. Survey basic-data rept., 639 p. 